\title{
The Impact of Using the Interactive Multimedia Book on Mathematics Learning: A Focus on 7th Grade Students Performance
}

\author{
Guedes António Caetano, Milton Zaro \\ Federal University of Rio Grande do Sul, Porto Alegre, Brazil \\ Email: guedyscaetano@gmail.com,zaro@ufrgs.br
}

How to cite this paper: Caetano, G. A., \& Zaro, M. (2018). The Impact of Using the Interactive Multimedia Book on Mathematics Learning: A Focus on 7th Grade Students Performance. Creative Education, 9, 2455-2476.

https://doi.org/10.4236/ce.2018.915185

Received: July 14, 2018

Accepted: November 13, 2018

Published: November 16, 2018

Copyright (c) 2018 by authors and Scientific Research Publishing Inc. This work is licensed under the Creative Commons Attribution International License (CC BY 4.0).

http://creativecommons.org/licenses/by/4.0/

(c) (i) Open Access

\begin{abstract}
Two experiments were developed to verify how the use of interactive multimedia books improves students' school performance in 7th grade math learning. The aim of the study was to compare the performance of students using the Multimedia Interactive Book with non-students in 7 th grade mathematics at a primary school in Mozambique, and was guided in two hypotheses. The null hypothesis was: the use of the interactive multimedia book in mathematics learning does not improve students performance and the alternative hypothesis was: the use of the interactive multimedia book in mathematics learning improves student's performance. The learning object was developed from the free web tool Edilim and 44 students aged between 11 and 17 participated in the study. The first experiment had 20 hours of study while the second experiment was 60 hours of study, totalling 80 hours of study. To assess the participants' cognitive development stage, the clinical method was used: operative tests of number, fluid and length preservation. The results of both experiments indicate that the use of the interactive multimedia book does not improve students' performance in math learning, corroborating with studies and theses that warn that the use of computers and multimedia resources does not improve students' performance in math learning.
\end{abstract}

\section{Keywords}

Performance, Learning Object, Interactive Multimedia Book, Method-Clinical

\section{Introduction}

Education is a decisive lever for the development of the human being and an in- 
dispensable tool for the fight against poverty and the promotion of the socio-economic development of the communities. However, governments do not always have the technical capabilities and socio-economic resources to provide their citizens' quality education. In this way, raising the quality of education has become a constant challenge for many countries, and more and more technological solutions are being sought to improve the quality of teaching and learning in schools. Africa is one of the continents where many countries are far from meeting acceptable quality standards of education, and Mozambique is one of them.

At present, it is verified that in Mozambique the quality of education at the primary level is not the best. Primary school pupils end the cycle and still have serious difficulties in calculating, reading and writing. Data from the Southern and Eastern Africa Consortium for Teaching Quality Monitoring (SACMEQ, 2010) indicate that between 2000 and 2007, levels in Mozambique have significantly deteriorated reading and math performance. SACMEQ concludes that Mozambique's decline of more than 40 points in reading and mathematics was associated with rapid structural changes in the education system in the period under review that resulted in massive increases in enrolment in the 6th grade without a corresponding increase in human resources and materials. On the other hand, the Report on the Five-Year Program of Government 2010-2014 states that the evaluations carried out reveal that the majority of Mozambican students in primary education have difficulties in reading and writing and basic arithmetic. The National Assessment Report of the 3rd class, conducted in 2014, states that "only 1 in 16 students is able to read simple sentences and infer information in a text" which means that only $6 \%$ of students in this class reach a level required at the end of the first cycle.

In Jordan, Nusir, Alsmadi, Al-Kabi, \& Sharadgah (2012) developed a study to investigate the impact of the use of multimedia technologies in improving or not improving the teaching effectiveness of students in early stages in primary schools. Two groups were selected at a local school. The experimental group was taught the subject of basic mathematics using a program developed for this purpose. The second class (control group) was taught the same subject using traditional teaching methods. The results showed that there is no significant difference in learning and knowledge skills and absorption of information based on gender distribution, where the comparison of results between boys and girls did not show significant difference in their learning abilities. However, Nusir, Alsmadi, Al-Kabi, \& Sharadgah (2012) selected the experimental and control group based on their own class distribution and data analyses were based on student performance and on gender distribution.

Similarly to the study presented above, this article presented an experimental study that took place in a primary school in Mozambique. However, the students who participated in the experiments were submitted to the clinical method-operative tests of number, fluid and length conservation to gauge the participants' cognitive development stage. In order to analyse the data, we used 
not only the students' performance but also the relationship between the students' socioeconomic situation and their performance, the students' satisfaction with the experience gained and the impact of the teacher's role on the students' performance.

In that way, the work focuses on the potential of the Web and Multimedia Services in the improvement of teaching methods, specifically in the production and use of multimedia books in the process of teaching and learning math in 7th grade. In this way, we intend to verify how the use of interactive multimedia books improves the school performance of students in maths learning of 7 th grade in Mozambique. In order to compare the performance of students using the Interactive Multimedia Book with students who do not use it in the 7th grade mathematics learning, the study was guided by two hypotheses: H0: The use of the interactive multimedia book in mathematics learning does not improve students' performance; H1: Using the interactive multimedia book in math learning improves student performance. The article is structured as follows: after the introduction, a basic literature review is presented, followed by the methodology. The following chapter presents the discussion of results, following the conclusions and recommendations. Finally, we present the acknowledgements and the references.

\section{Literature Review}

\subsection{Learning}

Within the multi-faceted landscape of theories and definitions of learning, there exists no general agreement on what learning really is, or on what is demanded of a definition of learning. Some proponents of theories of learning tend to advocate their own viewpoint and to consider learning theories as mutually exclusive and therefore incompatible (Qvortrup, Wiberg, Christensen, \& Hansbøl, 2016).

Becker (2003: p. 11) says that the great challenge of human learning lies in the difficult overcoming of conceptions based on common sense epistemologies, whether they are in hath or empiricists. To explain the learning process, Becker uses the Piagetian meaning of interaction.

Interaction means that knowledge begins neither in the subject (S) nor in the object $(\mathrm{O})$, but in an undifferentiated zone or in the periphery $(\mathrm{P})$ between subject and object. Any action of the subject always takes place on the object (material objects or physical world, culture, languages, concepts, history, arts, sciences, in the end, things, actions and relations among all these factors). Whenever the subject acts, assimilating, he does so in the direction of the centre (C) of the object - assimilate implies deciphering the object; when he encounters difficulties in this assimilative effort, that is, he feels incapable of assimilating insofar as he wishes to do so, he turns to himself and, in an effort of accommodation, produces transformations in himself ... The human being is the only one capable of appropriating the actions that he practiced, or rather the intimate mechanisms of these actions. Herein lies the secret of human unlimited capacity to learn 
(Becker, 2003: pp. 18-19).

De Oliveira (2011) says that in general, what is understood by learning is the capacity that the subject presents, in his daily life, to give answers adapted to the requests and challenges that are imposed to them during their interaction with the environment.

Currently, the theories that are most prominent in education are the theories developed by Jean Piaget and Lev Vygotsky (De Oliveira, 2011). The Genetic Epistemology developed by Piaget was developed through experience with children from birth to adolescence, based on the fact that knowledge is constructed from the interaction of the subject with his environment, from existing structures (Piaget, 1974). Vygotsky's studies, however, are based on the dialectic of the subject's interactions with the other and with the environment so that socio-cognitive development can occur (Vygotsky, 1999).

Piaget defines human learning as the construction of structures of assimilation, that is, learning is to construct structures of assimilation. In other words, we learn because we act to achieve something and, in a second moment, to appropriate the mechanisms of this first action. We learn because we act and not because we teach (Becker, 2003: p. 14).

According to Papalia, Olds and Feldman (2006) are two main theories of learning: Behaviorism and Theory of social learning, but we can also consider Constructivism as one of the most important today. Then Papalia, Olds and Feldman (2006) argue that according to the thinking of behaviourist authors, the conduct of the subject is amenable to observation and measurement. For this theory, the behaviours of the human being are learned, and with that, the learning aspect becomes of great importance. The environment has a fundamental role, since man becomes the product of the environment.

For Skinner (2006), the main characteristic of classical conditioning is that a person or animal learns a reflexive response to a stimulus that did not originally cause it, after the stimulus is repeatedly associated with another stimulus. Skinner (2006) also states that, in the case of operant conditioning, an originally accidental behaviour (for example, the smile), becomes a conditioned response, that is, the subject learns with the consequences of "operating" on the environment. De Oliveira (2011) states that from the studies with rats and pigeons, Skinner stated that the same principles could be applied to humans. With this he came to the conclusion that the subject tends to repeat a response that has been reinforced, and instead try to suppress a response that has been punished.

Assuming that the action of the subject builds knowledge, in this study we worked with the Piagetian concept of interaction. It was intended to introduce new forms of learning from the interaction of the students with a learning object.

Today, learning is understood as a global, dynamic, continuous, individual and progressive process. According to the school characteristics, there is a need for the student to be an active processor of the information transmitted to him, it is not enough just to be a passive receptor of knowledge, the student needs to decode what he is taught and thus absorb this knowledge (De Oliveira, 2011). 


\subsection{Defining Learning Object}

Ying \& Qunli (2011) state that Learning Object (LO) represents a kind of reusable digital instructional component. Being a new kind of education component, which based on the object-oriented programming paradigm, the LO has large values of application. Additionally, Ying \& Qunli (2011) say that if we define learning objects by the composition of Learning Objects, can include five parts, they are: learning objectives, metadata, content, practice and evaluation. Learning Object should be for specific teaching and learning independent existence.

According to Tarouco et al. (2014), Learning Object concept (LO) is neither easy nor consensual. Its definition arises according to its own conception about the usefulness and importance of the Object for teaching and learning and varies according to the proposed approach and the aspects that are associated with its educational use. For Wiley (2000), the notion of learning objects is confused in part because there are dozens of definitions of the term learning object (LO) as well as several phrases referring to the same notion of reusable digital educational resources. Wiley (2000) states that learning objects are elements of a new type of computer-based instruction based on the object-oriented paradigm of computer science. However, when it comes to searching for the concept of Learning Objects (LOs) many authors conceptualize the learning object as “... any entity, digital or non-digital, that can be used, reused or referenced during technology-supported learning” (Ying \& Qunli, 2011).

Behar (2009) understands by Learning Object any digital material, such as texts, animation, videos, images, applications, Web pages, in isolation or in combination, for educational purposes. These are autonomous resources, which can be used as modules of a given content or as a complete content. They are intended for learning situations in the distance or semi-presential or face-to-face mode. In this study, the concept we will be applying to LO is that referred to by Behar (2009). LOs can be created in any media or format, as simple as an animation or slide show, or complex as a simulation. Typically, they are created in modules that can be reused in different contexts (Tarouco et al., 2014). In this study a digital multimedia book was created using the Web tool EdiLim, with the purpose of teaching the contents of the maths discipline of 7 th grade in a primary school in Mozambique.

\section{State of Art}

There has been a long discussion about the efficiency and influence of the use of computers and multimedia resources in the teaching and learning process, and this debate is still open and inconclusive. While some argue that the use of computers and multimedia resources do not improve learning (Clark, 1994; Higgins, 2014; Loi \& Berge, 2015), others argue in opposition (Kozma, 1994; Moneta \& Moneta, 2002; Nokelainen, Miettinen, \& Ruohotie, 2008).

Studies presented by many authors (Nicholas, 2012; Moradmand, Datta, \& Oakley, 2014; Foster, Anthony, Clements, \& Sarama, 2016; Zaldívar-Colado, Al- 
varado-Vázquez, \& Rubio-Patrón, 2017) has confirmed that Information and Communication Technologies (ICT) help to improve math learning. Nicholas (2012) has developed a study to investigate whether Information and Communication Technologies (ICT) help improve the knowledge of rectangle geometry in a primary school. The applied educational software was composed of a history and various activities with and without the use of computers that were drawn following the antecedents of teaching mathematics realistic for concepts of geometry. In addition, it used a mathematical test called "Primary Shape Test" (PST) to explore the use of ICT in teaching basic geometric concepts of primary education. The results of the study indicated that teaching and learning through ICT is an interactive process for children in elementary school and has a positive effect on the formation of rectangle geometry.

Moradmand, Datta, \& Oakley (2014) say that there is often a disconnect between theory for the design of educational applications and theory regarding the application of technology in classrooms, as well as the lack of alignment between technology, curriculum and pedagogy. Thus, in many cases, obtaining computer-based technology and applications to facilitate learning in a pedagogically acceptable way for teachers have become a challenging area for schools. They developed a study that aimed to design and develop computer-based multimedia applications, based on a strong educational structure. To demonstrate the value of tools in facilitating math teaching and learning, the tools were offered to five different primary schools in Western Australia, of which three public schools, one private and one special in areas with different social and economic classes.

The results indicate that teachers were able to define and establish certain mathematical learning and teaching objectives that aligned with the Australian curriculum and to use the multimedia application as a teaching tool to teach the planned objectives. In addition, the application offered teachers multiple opportunities to model, share, and discuss a series of mathematical concepts within a story, in a multimodal fashion, and helped them to express various math concepts for children in an engaging and faster and deeper way than in the traditional way. The findings also reveal that software has helped to engage students' curiosity about mathematics, engaging them in the learning process, interacting with content, keeping them on task, eliciting sustained and useful classroom interaction, and to enable and enhance the learning of subject content individually and in pairs or small groups.

For Zaldívar-Colado, Alvarado-Vázquez, \& Rubio-Patrón (2017) the use of educational software offers many advantages, but it can also become a frustrating experience for teachers and students who do not have experience of use. The authors present an evaluation of the use of educational software in Mathematics to support the learning of first year primary students in the city of Mazatlán, Mexico. The aim of the study was to examine the impact of software (sacar 10) and introduce educational software to a first-year class of students. The study was carried out in three schools located in the urban area of the city of Mazatlan, Mexico.

The results indicate that the views on effective computer-based pedagogy are 
related to the types of software teachers used with their students. Regarding the results obtained in the study, software (sacar 10) supported and improved the learning of mathematics in general. This conclusion was obtained from the research responses, from the perspective of the teacher and from the perspective of the student. Overall, the study suggests from the surveys that the use of math educational software has a positive impact on student learning.

Foster, Anthony, Clements, \& Sarama (2016) present a study that evaluated the effects of a mathematical software program-The Building Blocks Mathematics Program-on the mathematical performance of young children. 247 Kindergartens from 37 classrooms participated in 9 schools located in low-income communities. Children in classrooms were randomly assigned to receive 21 weeks of computer-assisted instruction (CAI) in math with The Building Blocks Mathematics Program software. The results indicate that children who used The Building Blocks Mathematics Program showed higher post-test scores in numeracy tests and Applied Problems after checking for year-numbering score.

On the other hand, studies have revealed that the use of computers and multimedia resources does not improve learning. Nusir, Alsmadi, Al-Kabi, \& Sharadgah (2012) developed a study to investigate the impact of the use of multimedia technologies in improving or not improving the teaching effectiveness of students in early stages in primary schools in Jordan. Two groups were selected at a local school. The experimental group was taught the subject of basic mathematics using a program developed for this purpose. The second class (control group) was taught the same subject using traditional teaching methods. The results showed that the use of multimedia-enhanced teaching programs or methods can be effective in alerting students, especially when cartoon characters are used. The results also showed that there is no significant difference in learning and knowledge skills and absorption of information based on gender distribution, where the comparison of results between boys and girls did not show significant difference in their learning abilities.

Results of meta-analysis of experimental studies in which educational software was used to learn operations with fractions, decimals and percentages; plane and coordinate geometry; indexes, rates and proportions; operations with real and integer numbers; probability and data analysis; and measurement do not present significant statistical differences (Dynarski et al., 2007). On the other hand, when educational software is applied to the learning of algebra in schools, it is verified that the study time used in the educational software does not present a statistically significant correlation with a positive impact on student learning (Dynarski et al., 2007).

Hogrebe and Tate (2012) found that the individual socioeconomic status of poor communities is significantly related to students' performance in algebra, with students from low-income communities reaching lower levels than students from rich communities. Kitchen and Berk (2016) argued that computer-assisted instruction can focus only on basic skills for low-income students and minori- 
ties, further limiting their opportunities to learn mathematical reasoning. Here it is verified that the poverty of the societies is one of the factors that contributes to the poor performance of the students when submitted to a process of teaching and learning coupled with educational software.

According to the article entitled Computers' do not improve pupil results, says OECD by Coughlan (2015), published on 15 September 2015 on the BBC, it concludes that even when computers are used in the classroom, their impact on student performance is mixed, in best of all. Students who use computers moderately at school tend to have slightly better learning outcomes than students who rarely use computers. But students who use computers too often at school get worse learning outcomes. According to the same article, the results also do not show significant improvements in students' performance in reading, math or science in countries that have invested heavily in Information and Communication Technologies (ICT) for education. And perhaps the most disappointing finding is that technology seems to be of little help in overcoming the skills divided between favoured and disadvantaged students.

Based on the above concerns and conflicting results, it is important to examine how use of interactive multimedia books impacts performance in children's math learning.

\section{Methodology}

The study addresses a quantitative research that aimed to verify the impact of the use of interactive multimedia books on students' performance in mathematics. Two experiments were carried out and 44 students participated in the study (22 females and 22 males) from the 7th grade of a public primary school in Mozambique. The participants' ages range from 11 to 17 years.

\subsection{Data Collection}

The data collection techniques used were: observation, logbook, essay and Piagetian proof of number, liquid and length preservation. Observation was used to verify events in the classroom in loco; the logbook was used to note spontaneous or unexpected situations such as student tardiness, difficulties in interpreting or understanding LO; the essay was applied in the first experiment so that the students described their feelings in the face of the experience obtained, finally, to measure the degree of satisfaction of the participants-only the experimental group wrote the essay. In the second experiment, the clinical method was used for both groups in order to obtain information regarding the students' satisfaction with their performance.

The Piagetian proofs (of conservation of number, liquid and length) were introduced in order to verify if the students were in the stage that they were expected to be in their ages. It is known that to reach a certain cognitive stage there are several factors that compete to reach this stage. Having a certain age is not enough to conclude that someone has reached the corresponding stage for that 
age (may or may not be in the corresponding stage) but the individual is expected to be at this stage.

While in the first experiment the Piagetian tests were applied in the end, already in the second experiment they were applied at the beginning as one of the determining factors for the selection of the students who were able to participate in the experiment. Therefore, in the second experiment, in addition to the previous experience of computer use was also used as a criterion for the selection of students, the stage of cognitive development of the student in relation to their age.

In order to collect data regarding student performance, in the first experiment, two mathematical assessments were applied: the first evaluation focused on the matter of calculation of the area of geometric figures and contained six questions; and the second evaluation concerned the matter of percentage and permilia, and had six questions. In the second experiment, five evaluations were applied: the first evaluation focused on the subject of Reasons and Proportions; the second evaluation focused on the matter of Geometry (areas); the third evaluation focused on the matter of Guidance and location in the plan, Proportionality; the fourth evaluation focused on Geometry (Volume and Capacity), Some elements of statistics; and the fifth evaluation focused on the matter of Movements in the plan and Measures of time.

Both the experimental group as well as the control group were submitted to the same evaluations at the same time and in the same room. Once the evaluations were corrected, the notes were recorded in the teacher's notebook, identifying the respective group that each student belonged to.

\subsection{Characterization of Participants}

In all, 44 students from 7th grade were part of the experiments, 20 of them participated in the first experiment and 24 in the second experiment. In the first experiment, 10 male students and 10 female students participated. The age of the students in the first experiment was between 11 and 17 years, as can be seen in Table 1.

In the second experiment, 12 male students and 12 female students participated. The age of the students in the first experiment was between 12 and 14 years, as can be seen in Table 2 .

In the second experiment, in addition to the age and gender of the participants, data regarding the socio-economic characteristics of the participants were also collected. These data were introduced in the study in order to verify, that is, to look for some pattern that could relate the socio-economic characteristics (social environment) of the students with their academic performance during the school trimester. Piaget (1972) says that this temporal evolution is extremely variable; it depends on the previous experience of individuals, and not only on their maturation, and depends mainly on the social environment that can accelerate or delay the appearance of a stage, or even prevent its manifestation. Becker (2012) explains that much is talked about the creativity, but no explanation is brought about how the human being overcomes the boring repetitions, 
creating novelties or realizing new constructions. Continuing, Becker (2012) says that these novelties arise from the action of the subject that unfolds in time, although the age at which constructions of a certain complexity arise (the stages) can vary considerably from one to another individual. The following Table 3 and Table 4) show the socio-economic characteristics of the students of the experimental group (EG), see Table 3, and the control group (CG) of experiment II (Table 4).

Table 1. Age and gender of the participants of the experiment I $(n=20)$.

\begin{tabular}{ccccc}
\hline $\begin{array}{c}\text { Gender } \\
\text { Age }\end{array}$ & $\begin{array}{c}\text { Male } \\
\text { F }\end{array}$ & $\begin{array}{c}\text { Female } \\
\text { F }\end{array}$ & $\begin{array}{c}\text { Total } \\
\text { age } \mathrm{f}\end{array}$ & $\%$ \\
\hline $11-13$ & 4 & 8 & 12 & 60 \\
$14-17$ & 6 & 2 & 8 & 40 \\
Total & 10 & 10 & - & - \\
\hline
\end{tabular}

Source: the author.

Table 2. Age and gender of the participants of experiment II $(n=24)$.

\begin{tabular}{|c|c|c|c|c|}
\hline $\begin{array}{c}\text { Gender } \\
\text { Age }\end{array}$ & $\begin{array}{c}\text { Male } \\
\text { F }\end{array}$ & $\begin{array}{c}\text { Female } \\
\text { F }\end{array}$ & $\begin{array}{l}\text { Total } \\
\text { Age } \mathrm{f}\end{array}$ & $\%$ \\
\hline 12 & 3 & 9 & 12 & 50 \\
\hline 13 & 4 & 2 & 6 & 25 \\
\hline 14 & 6 & 1 & 6 & 25 \\
\hline Total & 12 & 12 & - & - \\
\hline
\end{tabular}

Source: the author.

Table 3. Socio-economic characteristics of students, EG $(n=12)$.

\begin{tabular}{|c|c|c|c|c|}
\hline Student(S) & Age & $\begin{array}{c}\text { Gender: Female }(F) \\
\text { Male }(M)\end{array}$ & Lives with & Occupation \\
\hline $\mathrm{S} 1$ & 12 & $\mathrm{~F}$ & Father and mother & Only father works \\
\hline $\mathrm{S} 2$ & 12 & $\mathrm{~F}$ & Father and mother & Both work \\
\hline S3 & 12 & $\mathrm{~F}$ & Father and mother & Only father works \\
\hline S4 & 12 & $\mathrm{~F}$ & Father and mother & Both work \\
\hline S5 & 13 & $\mathrm{~F}$ & Father and mother & Both work \\
\hline S6 & 12 & $\mathrm{~F}$ & Aunt & works \\
\hline S7 & 13 & M & Father and mother & Only father works \\
\hline S8 & 12 & M & Father and mother & Only father works \\
\hline S9 & 14 & M & Mother & works \\
\hline S10 & 14 & M & Mother & works \\
\hline S11 & 12 & M & Mother & works \\
\hline S12 & 12 & M & Mother & works \\
\hline
\end{tabular}

Source: the author. 
Table 4. Socio-economic characteristics of students, CG $(n=12)$.

\begin{tabular}{ccccc}
\hline Student(S) & Age & $\begin{array}{c}\text { Gender: Female (F) } \\
\text { Male (M) }\end{array}$ & Lives with & Occupation \\
\hline S1 & 12 & F & Father and mother & Only father works \\
S2 & 12 & F & Father and mother & Both work \\
S3 & 12 & F & Father and mother & Only father works \\
S4 & 12 & F & Father and mother & Both work \\
S5 & 13 & F & Mother & Works \\
S6 & 14 & F & Father and mother & Only father works \\
S7 & 13 & M & Mother & Works \\
S8 & 13 & M & Father and mother & Only father works \\
S9 & 14 & M & Mother & Works \\
S10 & 13 & M & Mother & Works \\
S11 & 14 & M & Grandmother & Retired \\
S12 & 14 & M & Mother & Works \\
\hline
\end{tabular}

Source: the author.

\subsection{Development of the Learning Object (Multimedia Interactive Book)}

The LO (Multimedia Interactive Book) was developed based on the Web tool EdiLim. EdiLim es el editor del sistema de autor Lim que permite crear pequeños objetos de aprendizaje interactivos. Es un editor multimedia que compendia las actividades a modo de páginas dentro de un libro. La variedad de actividades es extensa (51 tipos distintos de páginas) aunque no todas permiten interacción, un cierto porcentaje de ellas sirven para dar información. El manejo es muy sencillo, sólo se trata de seleccionar el tipo de página, seleccionar los elementos (textos, imágenes, animaciones) y ubicarlos en los lugares correspondientes. ${ }^{1}$

The LO was developed in the course of computer didactic discipline. Participated in the development of the LO four students of the degree in Computer Science of the Pedagogical University of Mozambique-Delegation of Nampula. For animation and modelling of figures and audio was used other software like Cantasia, Adobe Photoshop, CorelDraw, PowerPoint and Samplitude. The idea was to bring the same contents to be studied from the physical book to the Multimedia book. Thus, while the control group used the physical book in the learning of mathematics in the classroom of the school, the experimental group studied the same contents in the computer room using the interactive Multimedia book. The contents covered in LO were preceded by an audiovisual explanation accompanied by motivational exercises and challenges. The first page of the interactive Multimedia Book can be seen in Figure 1.

For the edition of the interactive book in EdiLim there are two key concepts: ${ }^{1}$ http://red.infd.edu.ar/articulos/edilim-un-sistema-de-autor/ 
each file is considered a book and each activity included within the book is a page. Each of these pages can be descriptive or interactive (games, multiple choice, fill in the blanks, etc.). The program also allows you to drag and drop audio files, text, images and animation files to provide illustration for activities.

On the other hand, it also allows creating activities with motivational feedback such as creating an activity of solving math problem and if the student hits receives applause and if he does not hit is booed. These types of activities were included in the $\mathrm{AO}$ in order to motivate students to find the right solution to the proposed exercises. You can also create games like puzzle, memory games, matching games, crosswords, etc. as can be seen in Figure 2.

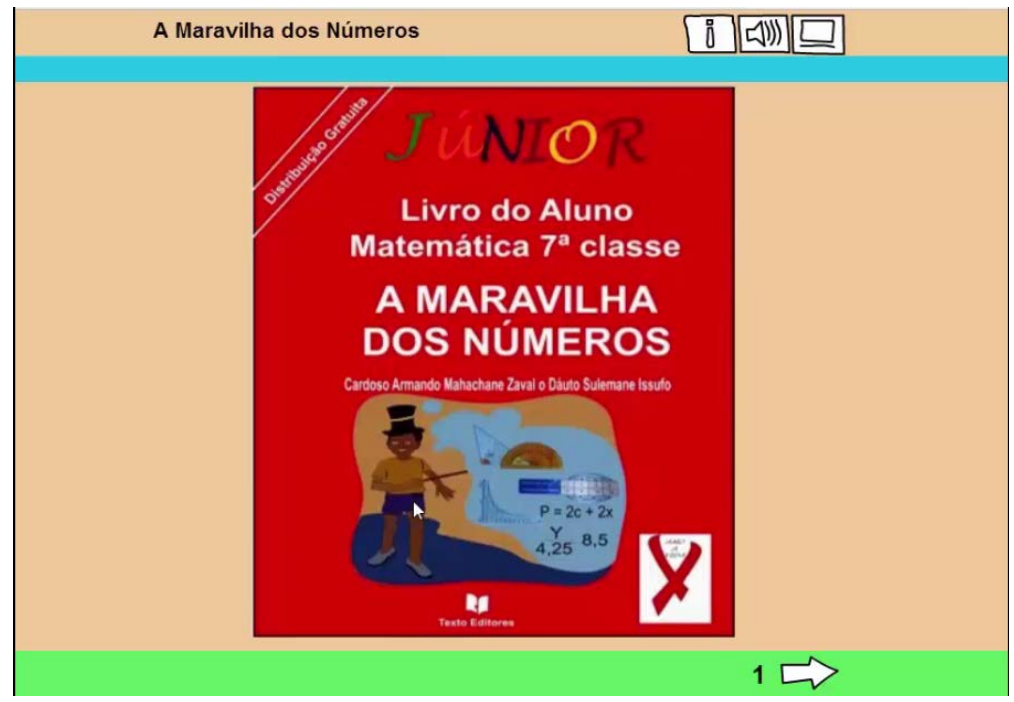

Figure 1. First page of the Interactive Multimedia Book. Source: Author Search.
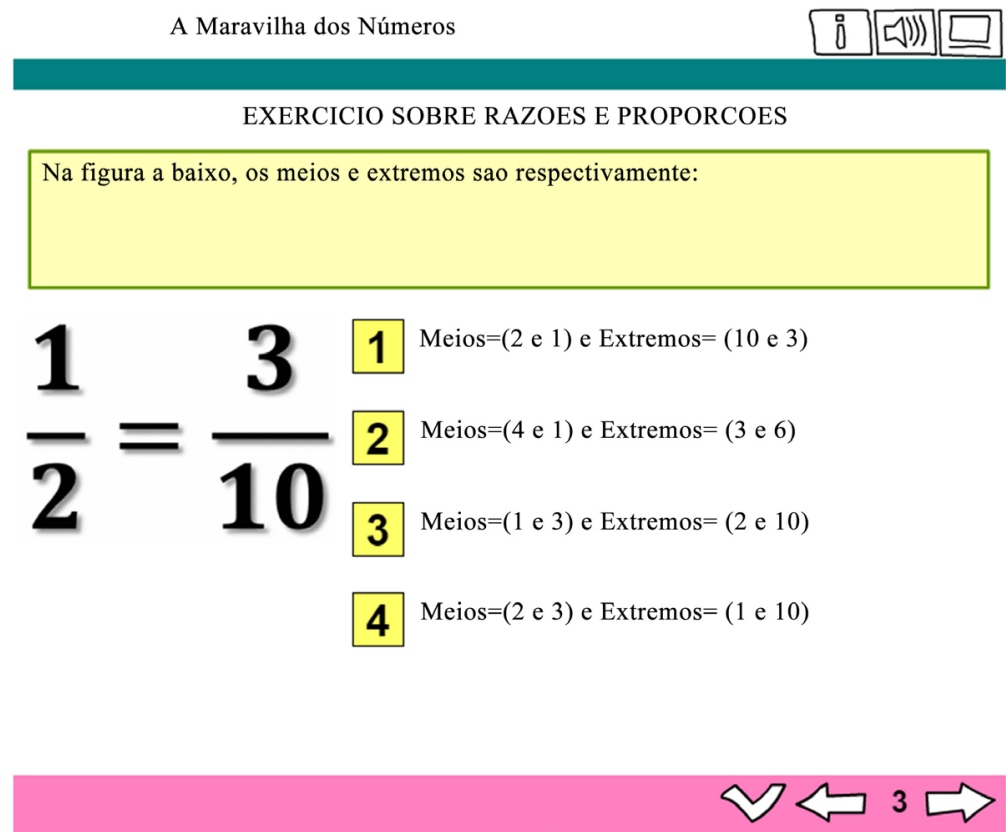

Figure 2. A LIM page: exercise on reasons and proportions. Source: Author Search. 


\subsection{Application of the Multimedia Interactive Instruments}

Currently the concept of multimedia is strictly associated with interactive media manipulated through a computer. For Vaughan (1996), Multimedia is any combination of text, graphic art, sound, animation and video presented to the user by a computer or other electronic medium.

Multimedia is an ideal device for presenting reality to the pupils. In many media combinations, the pupils are provided with possibilities of individually experiencing the presented reality. A multimedia stimulating environment in which the pupils find themselves encourages the pupil's individual experience of the world and freedom of choice of the media by which he/she most effectively learns (Rončević, 2009).

Currently it appears that many countries are introducing the use of multimedia resources in the teaching and learning process, whether at the primary, secondary or even higher level. Curtis (2014) states that it is unsurprising, therefore, that technology is playing an increasingly central role in the classroom - not just in ICT lessons, where children will start learning to write code from the age of five this year, but in English, Maths and Science lessons as well

However, despite considerable investments in computers, Internet connections and software for educational use, there is little solid evidence that greater computer use among students leads to better scores in mathematics and reading (OECD, 2015).

The same OECD (2015) report says that resources invested in ICT for education are not linked to improved student achievement in reading, mathematics or science. In countries where it is less common for students to use the Internet at school for schoolwork, students' performance in reading improved more rapidly than in countries where such use is more common, on average. Overall, the relationship between computer use at school and performance is graphically illustrated by a hill shape, which suggests that limited use of computers at school may be better than no use at all, but levels of computer use above the current OECD average are associated with significantly poorer results.

In summary, the OECD report (2015) points out that several studies (natural experiments) have assessed the impact on education outcomes of allocating more resources for ICT in schools. The majority of these studies find that such policies result in greater computer use in "treated" schools, but only few studies find positive effects on education outcomes, even when the new resources did not displace other investments. Evidence resulting from such "natural experiments" in Israel (Angrist \& Lavy, 2002), the Netherlands (Leuven et al., 2007), California (Goolsbee \& Guryan, 2006) and Peru (Cristia, Czerwonko, \& Garofalo, 2014) agrees with the finding of limited, and sometimes negative, effects on traditional performance indicators, such as test scores, grades in national examinations, and incidence of dropout. As an exception to these findings, Machin, McNally and Silva (2007) report performance gains from increased funding for ICT equipment among primary schools in England. 
In this study, the first experiment the study took place in a total of 20 hours. The classes were taught at the same time, but in different spaces. While the control group remained in school taking lessons in traditional methodology, the experimental group attended lessons in the computer room of the Pedagogical University of Mozambique. It should be noted that the two building are close to each other. The computer room contained 15 computers, a data show, two speakers, and a whiteboard. The student-computer distribution was one-to-one, that is, one student was to one computer. The contents were taught according to the pedagogical plan that was planned and made available by the group of maths teachers of the Primary School.

It was found that students were always lively and willing, that is, motivated to interact with LO. However, initially many of them had difficulty interacting with the computer's input peripherals like the mouse and the keyboard. Of the 10 students in the experimental group, only 3 had prior computer use experience. To overcome this difficulty it was necessary before proceeding to the study of mathematics, explaining the operation of these peripheral devices and how they should be used. A curious fact is that students easily appropriated these devices and started interacting with the multimedia book installed on the computer, and even when the class was over students did not want to leave the computer room, they wanted to continue interacting with LO. Lessons were held in the afternoon on Mondays, Tuesdays, and Wednesdays from 3:00 p.m. to 5:00 p.m. Each class had a duration of 45 minutes and two lessons were taught in a row, that is, in total the lessons were 90 minutes.

During classes with LO, students could interact with each other by helping each other both in explaining the subject and in interacting with LO. Thus, if a certain task was not clear they could ask the teacher as well as one of the classmates for help.

The second experiment was carried out in the last quarter of the academic year of 2017. In total, 60 hours of study were carried out and the thematic units studied were: Reasons and Proportions, Geometry (areas), Orientation and location in the plan, Proportionality, Geometry (Volume and Capacity), Some elements of statistics, Movements in the plan, Measures of time.

Although the students said that they had previous experiences of computer use, it was found that at the beginning of the activities with the interactive multimedia book the students presented difficulties in moving the mouse and the keyboard. To overcome these difficulties it was necessary to give the students an introductory lecture on the organization and use of the computer. The classes took place in the morning on Tuesdays, Wednesdays and Thursdays. On Tuesdays, much of the experimental group was late in class. This delay also occurred in the control group because the classes started at 6:30 in the morning. It was also found that students who arrived late in class lived far from school and that there were students who lived more than $3 \mathrm{~km}$ from school. The classroom contained 15 computers, 4 ceiling fans, and two air conditioners installed. The initial student computer distribution was two students to one computer, and after 
the first test the distribution of 2 students to 1 computer was undone because from the beginning the students insisted on distribution 1 student per computer and not 2 students per computer, thus accommodating the requirements of the students.

Due to the fact that the sense of population and housing in Mozambique from August 1 to 15, 2017, and having extended for another week of sensing, the classes only started in the week of August 28, 2017 because large primary and secondary school teachers were involved in these activities. This action led to the restructuring and the dynamics in the implementation of the thematic plan of the school, causing that per week instead of 5 hours of work the students had to have 6 hours in the discipline of mathematics. Thus, although the initial dosage did not suffer changes in content, it was found that weekly the analytical plan was modified to accommodate the objectives of the discipline in each thematic plan.

In the first two weeks the students of the experimental group were very motivated and happy, but then became more interested in computer games than the LO. To change this situation the researcher had to agree with the students so that they focused more on the LO during the classes so they could play cards and other games in the morning on Saturdays. Thus, the agreement was who deviated from the class would not have access to the computer room on Saturdays. It should be noted that on Saturdays access to the computer room was also open to students of the control group.

The date of 25 September is the date of Mozambique's independence. In the week of September 25 to October 1, 2017, there was a weak turnout of students and some teachers in school. The students who missed this week justified themselves by saying that they were not sure if they would have classes this week. Others were justified by reporting experiences from the previous year in which, in the week in which Independence Day was celebrated, thus, the week of September 25 , many teachers missed classes. In total, 8 students were absent during the week, 3 of EG (S5, S7 and S11) and 5 of CG (S4, S6, S7, S9 and S12). It is important to note that of the 3 students who were absent in EG, the A11 student missed two weeks due to illness (malaria).

\section{Results and Discussion}

In this study we used the Classic Plan of the Experiment with variations. Specifying, the control group plan was used, but where only the post-test is used. This method was selected because of the space constraint (computer room) to perform the experiment. Experimental group worked in one of the computer rooms of Pedagogical University of Mozambique while Control Group continued to work in Primary School. As the university and the school have different academic calendars it was necessary to wait the period of vacations in the university to use the computer room with Experimental Group.

To verify how the LO affects student performance, two evaluations were performed in experiment I and five evaluations in experiment II. The next step was 
to calculate the average of each student. The average of the averages was then calculated, that is, the mean of each student was added, and the total was divided by the total number of students in each group of the experiments. To this mean of the means was called the total average and was taken as the post-test value of each group. The scale used in the grading notes is from zero (0) to twenty (20). The following Tables 5-8 show the EG and CG scores, standard deviation and the respective student $t$ test of both experiments:

Experiment I

Table 5. Experimental group ratings tests.

\begin{tabular}{cccccc}
\hline & \multicolumn{2}{c}{ EXPERIMENTAL GROUP (EG) } & \\
Students (S) & Age & Sex & Tests & Average \\
\cline { 4 - 5 } S1 & 17 & M & 7 & 7 & 7 \\
S2 & 12 & F & 7 & 10 & 8.5 \\
S3 & 15 & M & 15 & 16 & 15.5 \\
S4 & 12 & F & 11 & 10 & 10.5 \\
S5 & 12 & M & 7 & 8 & 7.5 \\
S6 & 13 & M & 15 & 16 & 15.5 \\
S7 & 11 & F & 0 & 6 & 3 \\
S8 & 12 & M & 8.5 & 4 & 6.25 \\
S9 & 17 & F & 14 & 15 & 14.5 \\
S10 & 15 & F & 3 & 3 & 3 \\
& TOTAL AVERAGE & & & 9.1 \\
\end{tabular}

Source: the author.

Table 6. Control group ratings tests.

\begin{tabular}{cccccc}
\hline & \multicolumn{4}{c}{ CONTROL GROUP (CG) } & \\
\cline { 4 - 5 } Student(S) & Age & Sex & Tests & Average \\
\cline { 4 - 5 } S1 & 14 & M & 7 & 10 & 8.5 \\
S2 & 13 & M & 7 & 3 & 5 \\
S3 & 14 & M & 12 & 8 & 10 \\
S4 & 12 & F & 4 & 9 & 6.5 \\
S5 & 12 & M & 14 & 12 & 13 \\
S6 & 13 & F & 3 & 6 & 4.5 \\
S7 & 12 & F & 10 & 9 & 9.5 \\
S8 & 14 & M & 12 & 9 & 10.5 \\
S9 & 13 & F & 7 & 10 & 8.5 \\
S10 & 14 & F & 7 & 9 & 8 \\
& TOTAL AVERAGE & & & 8.4
\end{tabular}

Source: the author. 
In experiment I we have the following results: TOTAL AVERAGE (EG) $=9.1$ and TOTAL AVERAGE (CG) $=$ 8.4. TOTAL AVERAGE (EG) > TOTAL AVERAGE (CG). To analyze our data we use statistical techniques of data inference. Based on the size of our sample $(n=20)$, the appropriate technique to interpret the data is the use of the t-test (Student's t-test). Once the calculations were done $\mathrm{t}=0.41$ and the Critical Value $\mathrm{VC}=1.734$. Comparing our value $\mathrm{t}=$ 0.41 with $\mathrm{CV}=1734$ we find that $\mathrm{t}<\mathrm{CV}$. When $\mathrm{t}<\mathrm{CV}$ there is no evidence to reject $\mathrm{H} 0$. Thus we accept the null hypothesis $\mathrm{HO}$ and reject the alternative hypothesis H1. Thus, it can be stated with a 95\% confidence level that the use of the interactive multimedia book in math learning does not improve student performance.

\section{EXPERIMENT II}

Table 7. Results of Experimental Group evaluations.

\begin{tabular}{|c|c|c|c|c|c|c|}
\hline \multirow{2}{*}{ Student (S) } & \multicolumn{5}{|c|}{ Tests } & \multirow{2}{*}{ Average } \\
\hline & $\mathrm{T} 1$ & $\mathrm{~T} 2$ & T3 & $\mathrm{T} 4$ & T5 & \\
\hline S1 & 10.5 & 13 & 12 & 10 & 11.7 & 11.4 \\
\hline S2 & 10.5 & 10 & 12 & 11 & 14 & 11.5 \\
\hline S3 & 7.5 & 6.5 & 12 & 13 & 14 & 10.6 \\
\hline S4 & 14.5 & 20 & 16 & 15 & 14 & 15.9 \\
\hline S5 & 14.5 & 12 & 13 & 13 & 14 & 13.3 \\
\hline S6 & 5.5 & 7.5 & 12 & 11 & 9 & 9.0 \\
\hline S7 & 10.5 & 7.5 & 12 & 11 & 14 & 11.0 \\
\hline S8 & 9 & 13.5 & 10 & 11 & 10 & 10.7 \\
\hline S9 & 10 & 11 & 12 & 10 & 7.5 & 10.1 \\
\hline S10 & 10 & 4.5 & 11 & 10 & 11 & 9.3 \\
\hline S11 & 10.5 & 6 & 12 & 11 & 10.8 & 10.1 \\
\hline S12 & 11.5 & 12.5 & 13 & 12 & 10 & 11.8 \\
\hline \multicolumn{6}{|c|}{ Total average } & 11.2 \\
\hline \multicolumn{6}{|c|}{ Standard deviation } & 1.9 \\
\hline \multicolumn{6}{|c|}{$\mathrm{n}$} & 12 \\
\hline
\end{tabular}

Source: the author.

Table 8. Results of Control Group evaluations.

\begin{tabular}{ccccccc}
\hline \multirow{2}{*}{ Student (S) } & \multicolumn{5}{c}{ Tests } & \multirow{2}{*}{ Average } \\
\cline { 2 - 5 } & T1 & T2 & T3 & T4 & T5 & \\
\hline S1 & 14.5 & 20 & 16 & 13 & 11 & 14.9 \\
S2 & 18 & 20 & 15 & 10 & 14 & 15.4 \\
S3 & 13 & 20 & 14 & 13 & 14 & 14.8 \\
S4 & 10 & 13 & 11 & 11 & 10 & 11.0 \\
\hline
\end{tabular}




\begin{tabular}{ccccccc} 
Continued & \multicolumn{7}{c}{} \\
\hline S5 & 10.5 & 14 & 12 & 13 & 13.5 & 12.6 \\
S6 & 10.5 & 11 & 12 & 12 & 14.5 & 12.0 \\
S7 & 11.5 & 16 & 10 & 10 & 10 & 11.5 \\
S8 & 10.5 & 13.5 & 12 & 16 & 12 & 12.8 \\
S9 & 11.5 & 10 & 13 & 10 & 10 & 10.9 \\
S10 & 13 & 16 & 14 & 10 & 10 & 12.6 \\
S11 & 13.5 & 10 & 11 & 10 & 10 & 10.9 \\
S12 & 9 & 16 & 10 & 10 & 11 & 11.2 \\
& & Total average & & & 12.6 \\
& & Standard deviation & & & 1.6 \\
\hline
\end{tabular}

Source: the author.

In this experiment we obtain the value of the test $t=-1.95$, degrees of free$\mathrm{dom}=22$ and the critical value $\mathrm{CV}=2.074$. Comparing our value $\mathrm{t}=-1.95$ with $\mathrm{CV}=2.074$ we find that $\mathrm{t}<\mathrm{CV}$. When $\mathrm{t}<\mathrm{CV}$ there is no evidence to reject $\mathrm{H} 0$. Thus we accept the null hypothesis $\mathrm{H} 0$ and reject the alternative hypothesis $\mathrm{H} 1$.

Thus, it is found that in both experiment I and experiment II there is no evidence to reject the null hypothesis. Thus, we can state with a 95\% confidence level that using the interactive multimedia book in math learning does not improve student performance.

Another important data to observe in both experiments is the standard deviation. The standard deviation is a measure that indicates the dispersion of data within a sample relative to the mean. In both experiments it was found that the standard deviation of the experimental group was greater than the standard deviation of the control group, i.e. in terms of performance there was more dispersion in the tests of the experimental group compared to the control group and greater cohesion in the results of the control group compared to the experimental group.

This dispersion, this poor performance of the experimental group can be attributed to external factors such as the previous experience of the students on the use of computer, the adaptation to the interactive multimedia book and the learning environment in which the learning took place. It may also be linked to the threat of internal validity and control of the experiment variables. Internal validity is the degree to which the design of an experiment controls extraneous variables (Borg et al., 1993). It may be that the control group has had better preparation for the tests. It is important to note that in the second experiment, the school provided the best mathematics teacher's class for the research. In this way, twelve students from the class were part of the experimental group and another twelve students were part of the control group. The experimental group started taking classes at the university with another teacher using the Multime- 
dia Interactive Book while the control group stayed in school with the teacher.

The 12 students in the control group of the 2nd experiment were individually questioned (how did you obtain this result in the tests) and a tendency (standard) in the students' responses showed a strong relation between the teacher's attitude and the good students' performance as we can see: 4 of them answered-"the teacher explains well", another 5 answered-“I understand the subject because I like the teacher and I have already gotten used to her lessons", and 3 students answered- "I like the teacher, was my teacher last year."

Another interesting fact that has been observed in both groups (EG and CG) in the first experiment is that the students who scored more on the tests had common characteristics: they lived with their parents; father and mother work, or at least one of them works. In this way, it can be concluded that one of the key factors for the success of learning is related to the socio-economic condition of the students. The social condition of the student is linked to affection and plays a primordial role in the functioning of intelligence. This fact is strongly defended by Piaget (1962) when says:

It is undeniable that affection plays an essential role in the functioning of intelligence. Without affection there would be no interest, no need, no motivation; and consequently, questions or problems would never be posed and there would be no intelligence. Affectivity is a necessary condition in the constitution of intelligence but, in my opinion, is not enough.

\section{Conclusion and Recommendations}

The use of the interactive multimedia book was a new approach to monetize digital resources in favour of learning math. The experiment allowed students to experience a new approach to math learning that is believed to have enabled students to change their way of thinking and learn math using their computer.

From the results of the experiments, it is verified that the use of the interactive multimedia book does not improve the performance of the students in the learning of mathematics. However, it is clear that interactive multimedia books can be used as a complementary pedagogical resource in the teaching and learning process of mathematics since students have liked to use this tool.

For the students, it was a new experience that they liked, since they had never before taken classes using interactive multimedia books. This experience of the students opens the way for digital inclusion in the teaching and learning process, and they can gradually take digital resources for learning mathematics and other subjects.

Despite the motivation of the students to want to learn mathematics through the computer, it is verified that through the analysis of the test $t$ that the performance of the experimental group is not significantly higher to say that the experimental factor, the interactive multimedia book, improved the performance of students in math learning.

On the other hand, it was verified that in both experiments there was more 
dispersion of the tests in relation to the mean in the experimental group. That is, the experimental group was less cohesive in relation to the control group.

It can also be seen from the socioeconomic data of the participants that students with good socioeconomic conditions presented better performance in both groups. That is, they tend to be more successful in the Teaching and Learning Process in relation to those who do not have good socioeconomic conditions.

Based on the clinical interviews, it can be said that the role of the teacher and the good student-teacher relationship is a key factor to take into account when it is intended to improve student performance. A teacher present in the school life of the students, well planned, assiduous and motivated, will have students with good academic performance in relation to a teacher less assiduous, less planned and demotivated.

The student's previous experience with the use of computers and digital media is a key factor in the appropriation and use of Multimedia Interactive Books. Students without experience of computer use will present, first, difficulties of computer use and second difficulties of appropriation of the Multimedia Interactive Book.

\section{Suggestions}

This study contributes to the analysis and implementation of Multimedia Interactive Books as LO in the Teaching and Learning Process of primary school mathematics. The results obtained suggest the training of teachers and students on computer use and the use of Interactive Multimedia Books as a way of framing this resource in the Teaching and Learning Process of primary schools. For this, the teacher must be motivated because it is verified that the role of the teacher is a preponderant characteristic for the success and good performance of the student.

It is also suggested that the Ministry of Education and Human Development of Mozambique should employ psychologists in schools to monitor students' cognitive development and learning.

\section{Acknowledgements}

We are grateful to the Nampula District Education, Youth and Technology Services; to the teachers and the director of Napipine Primary school, Mozambique; the Mozambique Pedagogical University, Delegation of Nampula; the Federal University of Rio Grande do Sul, Brazil and the National Council for Scientific and Technological Development (CNPQ), Brazil.

\section{Conflicts of Interest}

The authors declare no conflicts of interest regarding the publication of this paper.

\section{References}

Angrist, J., \& Lavy, V. (2002). New Evidence on Classroom Computers and Pupil Learn- 
ing. Economic Journal, 112/482, 735-765.

https://doi.org/10.1111/1468-0297.00068n

Becker, F. (2003). A origem do conhecimento e a aprendizagem escolar [The Origin of Knowledge and School Learning]. Porto Alegre: Artmed Editora.

Becker, F. (2012). Educação e construção do conhecimento [Education and Knowledge Construction] ( $2^{\mathrm{a}}$ edição). Porto Alegre: Penso.

Behar, P. A. (2009). Modelos pedagógicos em educação a distância [Pedagogical Models in Distance Education]. Porto Alegre: Artmed Editora.

Borg, W. R., Gall, J. P., \& Gall, M. D. (1993). Applying Educational Research (3rd Ed.). New York: Longman.

Clark, R. E. (1994). Mídia Will Never Influence Learning. Educational Technology Research and Development, 42, 21-29.

Coughlan, S. (2015). Computers "Do Not Improve" Pupil Results, Says OECD Featured on the BBC [Blog Post]. http://www.bbc.com/news/business-34174796

Cristia, J., Czerwonko, A., \& Garofalo, P. (2014). Does Technology in Schools Affect Repetition, Dropout and Enrolment? Evidence from Peru. IDB Working Paper Series, No. IDB-WP-477, Inter-American Development Bank, Research Department.

Curtis, S. (2014). Digital Learning: How Technology Is Reshaping Teaching Featured on the Telegraph.

https://www.telegraph.co.uk/technology/news/11051228/Digital-learning-how-technol ogy-is-reshaping-teaching.html

De Oliveira, L. P.( 2011). Psicologia da aprendizagem e do desenvolvimento [Psychology of Learning and Development]. Centro universitário de maringá. núcleo de educação a distância.

Dynarski, M., Agodini, R., Heaviside, S., Novak, T., Carey, N., Campuzano, L., \& Sussex, W. (2007). Effectiveness of Reading and Mathematics Software Products: Findings from the First Student Cohort (NCEE 2007-4005). Washington DC: US Department of Education, Institute of Education Sciences.

Foster, M. E., Anthony, J. L., Clements, D. H., \& Sarama, J. (2016). Improving Mathematics Learning of Kindergarten Students through Computer Assisted Instruction. Journal for Research in Mathematics Education, 47, 206-232.

https://doi.org/10.5951/jresematheduc.47.3.0206

Goolsbee, A., \& Guryan, J. (2006). The Impact of Internet Subsidies in Public Schools. The Review of Economics and Statistics, 88, 336-347. https://doi.org/10.1162/rest.88.2.336

Higgins, S. (2014). Does ICT Improve Learning and Teaching in Schools? Newcastle University.

Hogrebe, M. C., \& Tate, W. F. (2012). Place, Poverty, and Algebra: A Statewide Comparative Spatial Analysis of Variable Relationships. Journal of Mathematics Education at Teachers College, 3, 12-24.

Kitchen, R. S., \& Berk, S. (2016). Educational Technology: An Equity Challenge to the Common Core. Journal for Research in Mathematics Education, 47, 3-16. https://doi.org/10.5951/jresematheduc.47.1.0003

Kozma, R. B. (1994). Will Media Influence Learning? Reframing the Debate. Educational Technology Research and Development, 42, 7-19.

Leuven, E., Lindahl, M., Oosterbeek, H., \& Webbink, D. (2007). The Effect of Extra Funding for Disadvantaged Pupils on Achievement. The Review of Economics and Statistics, 89, 721-736. https://doi.org/10.1162/rest.89.4.721

Loi, M., \& Berge, O. (2015). Assessing the Effects of ICT on Learning Outcomes. Norwe- 
gian Centre for ICT in Education, ISBN 978-82-93378-29-7.

Machin, S., McNally, S., \& Silva, O. (2007). New Technology in Schools: Is There a Payoff? Economic Journal, 117, 1145-1167. https://doi.org/10.1111/j.1468-0297.2007.02070.x

Moneta, S. K., \& Moneta, G. B. (2002). E-Learning in Hong Kong: Comparing Learning Outcomes in Online Multimedia and Lecture Versions of an Introductory Computing Course. British Journal of Educational Technology, 33, No. 4.

Moradmand, N., Datta, A., \& Oakley, G. (2014). The Design and Implementation of an Educational Multimedia Mathematics Software: Using ADDIE to Guide Instructional System Design. The Journal of Applied Instructional Design, 4, 37-49.

Nicholas, Z. (2012). The Use of Information and Communication Technologies in the First Grade of Primary School for Teaching Rectangles Based in Realistic Mathematics Education. Heraklion: Department of Preschool Education University of Crete Rethymno.

Nokelainen, P., Miettinen, M., \& Ruohotie, P. (2008). Modeling of Learning Outcomes, Activities and Profiles in a CSLE. World Conference on Educational Multimedia, Hypermedia and Telecommunications, 2008, 437-446.

Nusir, N., Alsmadi, I., Al-Kabi, M., \& Sharadgah, F. (2012). Studying the Impact of Using Multimedia Interactive Programs at Children Ability to Learn Basic Math Skills. ActaDidactica Napocensia, 5, 17e32.

OECD (2015). Students, Computers and Learning: Making the Connection. PISA, OECD Publishing.

Papalia, D. E., Olds, S. W., \& Feldman, R. D. (2006). Human Development. Porto Alegre: Artmed.

Piaget, J. (1962). The Relation of Affectivity to Intelligence in the Mental Development of the Child. Bulletin of the Menninger Clinic, 26, 6, 13 and 22.

Piaget, J. (1974). Learning and Knowledge. Rio de Janeiro: Freitas Bastos.

Qvortrup, A., Wiberg, M., Christensen, G., \& Hansbøl, M. (2016). On the Definition of Learning. University Press of Southern Denmark.

Rončević, A. (2009). Multimedia in Primary School. Doctoral Thesis, Ljubljana: Faculty of Education.

Skinner, B. F. (2006). About Behaviorism. São Paulo: Cultrix.

Southern and Eastern Africa Consortium for Monitoring Education Quality. (2010).

Tarouco, L. M. R., Costa, V. M., Ávila, B. G., Bez, M. R., \& Dos Santos, E. F. (2014). Learning Objects: Theory and Practice. Porto Alegre: Editora Evangraf Ltda.

Vaughan, T. (1996). Multimedia Making It Work (3rd Ed.). Osborne: McGraw-Hill.

Vygotsky, L. S. (1999). Psychological Development in Childhood. São Paulo: Martins Fontes.

Wiley, D. A. (2000). Learning Object Design and Sequencing Theory. Brigham Young University. http://www.opencontent.org/openpub/

Ying, Z., \& Qunli, S. (2011). Design and Development of Mobile Learning Resources Based on Learning Object. In International Conference on Electrical and Control Engineering (pp. 6486-6489). Piscataway, NJ: Institute of Electrical and Electronics Engineers. https://doi.org/10.1109/ICECENG.2011.6056877

Zaldívar-Colado et al. (2017). Evaluation of Using Mathematics Educational Software for the Learning of First-Year Primary School Students. Education Sciences, 7, 79.

https://doi.org/10.3390/educsci7040079 